\title{
A biotechnological expansion of shellfish cultivation could permanently remove carbon dioxide from the atmosphere
}

\section{Una ampliación biotecnológica del cultivo de moluscos bivalvos podría eliminar permanentemente el dióxido de carbono de la atmósfera}

David Moore

School of Biological Sciences, Faculty of Biology, Medicine and Health, The University of Manchester, Manchester, United Kingdom.

${ }^{*}$ Corresponding author

E-mail address: david@davidmoore.org.uk (D. Moore) (retired from the University of Manchester).

Article history:

Received: 14 November 2019 / Received in revised form: 15 December 2019 / Accepted: 16 December 2019 / Published online: 1 January 2020.

https://doi.org/10.29267/mxjb.2020.5.1.1

\begin{abstract}
To combat climate change, proposals have been made to develop methods that would pull carbon dioxide out of Earth's atmosphere. One recommended approach is to remove $\mathrm{CO}_{2}$ from the atmosphere with activities such as reforestation and changing forest management and agricultural practices to enhance soil carbon storage. However, it is also noted that such activities would limit land for food production and negatively affect biodiversity. Furthermore, decay of dead wood and fallen leaves in natural forests releases huge quantities of $\mathrm{CO}_{2}$ and other greenhouse gases back into the atmosphere. The only other carbon-sequestration technique that is widely considered is the application of $\mathrm{CO}_{2}$ capture processes to flue gases of power plants, which are responsible for about $80 \%$ of the worldwide $\mathrm{CO}_{2}$ emission from large stationary sources. Hydrate-based processing is a promising technology for $\mathrm{CO}_{2}$ capture as it results in high $\mathrm{CO}_{2}$ recovery, but its high cost prevents this technology having much impact. In this note I suggest that the ability of marine organisms (shellfish and coccolithophore algae) to remove permanently $\mathrm{CO}_{2}$ from the atmosphere into solid (crystalline) $\mathrm{CaCO}_{3}$ should be harnessed. I suggest that if the level of finance and effort that are readily
\end{abstract}


anticipated for forest management and flue gas treatments were to be applied to expansion of shellfish cultivation around the world, significant amounts of carbon dioxide could be permanently removed from the atmosphere within the timescale that is currently envisaged for carbon capture by afforestation.

Key Words: aquaculture, atmosphere remediation, carbon capture, carbon dioxide, shellfish, shell- $\mathrm{CaCO}_{3}$.

\section{RESUMEN}

Para combatir el cambio climático, se han hecho propuestas para desarrollar métodos que eliminen el dióxido de carbono de la atmósfera terrestre. Un enfoque recomendado es eliminar el $\mathrm{CO}_{2}$ de la atmósfera con actividades como la reforestación, y el cambio en la gestión forestal y las prácticas agrícolas para mejorar el almacenamiento de carbono del suelo. Sin embargo, esas actividades limitarían la tierra para la producción de alimentos y afectarían negativamente a la biodiversidad. Además, la descomposición de la madera muerta y las hojas caídas en los bosques naturales libera enormes cantidades de $\mathrm{CO}_{2}$ y otros gases de efecto invernadero a la atmósfera. La única otra técnica de secuestro de carbono que es ampliamente considerada es la aplicación de procesos de captura de $\mathrm{CO}_{2}$ de los gases de combustión de las centrales eléctricas, que son responsables de aproximadamente el $80 \%$ de la emisión mundial de $\mathrm{CO}_{2}$ de grandes fuentes estacionarias. El proceso basado en la producción de hidrógeno con captura de $\mathrm{CO}_{2}$ es una tecnología prometedora para la captura de $\mathrm{CO}_{2}$, ya que resulta en una alta recuperación de éste gas, pero su alto costo evita que esta tecnología tenga mucho impacto. En esta nota sugiero que se aproveche la capacidad de los organismos marinos (moluscos bivalvos) para eliminar permanentemente el $\mathrm{CO}_{2}$ de la atmósfera en sólido (cristalino) $\mathrm{CaCO}_{3}$. Sugiero que, si el nivel de financiamiento y esfuerzo que se preveé fácilmente para la gestión forestal y los tratamientos de gases de combustión se aplicaran a la ampliación del cultivo de moluscos bivalvos en todo el mundo, se podrían eliminar permanentemente cantidades significativas de dióxido de carbono de la atmósfera dentro del plazo previsto actualmente para la captura de carbono por reforestación.

Palabras clave: acuicultura, captura de carbono, $\mathrm{CaCO}_{3}$ de concha de moluscos bivalvos, dióxido de carbono, moluscos bivalvos, remediación atmosférica.

\section{INTRODUCTION}

Photosynthetic carbon capture by trees is widely considered to be possibly our most effective strategy to limit the rise of $\mathrm{CO}_{2}$ concentrations in the atmosphere, and there are several ambitious targets to promote forest conservation, afforestation, and restoration on a global scale.

The Intergovernmental Panel on Climate Change Special Report of 2018 (IPCC, 2018) suggested that an increase of 1 billion hectares of forest will be necessary to limit global warming to $1.5^{\circ} \mathrm{C}$ by 2050 . Bastin et al. (2019) mapped the global potential tree coverage and estimated that the world's ecosystems could support 
an additional 0.9 billion hectares of continuous forest (corresponding to more than $25 \%$ increase in forested area) and that such a change has the potential to cut the atmospheric carbon pool by about $25 \%$. I like trees and I am all in favour of planting more of them, but as a mycologist I have to say that there is a negative side to these estimations that seems to be escaping notice.

This is that forests don't only contain trees that can store gigatonnes of carbon in the wood they make; forests also contain wood-decaying fungi that can (and do) digest that wood, releasing greenhouse gases, including $\mathrm{CO}_{2}$, in the process.

Chlorinated hydrocarbons also make a normal every-day contribution to the degradation of timber. The fungal chloromethane contribution to the atmosphere has been estimated at around 150,000 tonnes per annum (Watling \& Harper, 1998), which is about $60 \%$ more than was released into the atmosphere by industrial coal burning furnaces worldwide in the year of publication.

Of course, the ultimate end-product of digestion is $\mathrm{CO}_{2}$. On a global scale, decomposition of seasonally shed leaves, petals, ripe fruit, and dead wood releases billions of tons of $\mathrm{CO}_{2}$ to the atmosphere each year, a similar magnitude, in fact, to the annual $\mathrm{CO}_{2}$ emissions from fossil fuel combustion (Rinne-Garmston et al., 2019).

However, Boysen et al. (2017) note that using biomass plantations to sequester carbon would reduce biodiversity, because they are likely to be monocultures, and occupy land that might otherwise be used for food production. These authors conclude: '...that this strategy of sequestering carbon is not a viable alternative to aggressive emission reductions...'

Most current research on 'aggressive emission reductions' is focussed on the integration of new technologies to capture $\mathrm{CO}_{2}$ from flue gasses in power plants, which are responsible for about $80 \%$ of the worldwide $\mathrm{CO}_{2}$ emissions (Romano et al., 2013). Methods based on exposing flue gas to water under suitable conditions ('hydrate-based processing') is a promising and high efficiency technology for $\mathrm{CO}_{2}$ capture, but the high cost of maintaining suitable conditions for hydrate formation is preventing wide industrial application of this technology (Li et al., 2019).

So, if the forests and capture from flue gases can't save us, are we doomed? Well, no, actually; we just need to change our focus; turn away from trees (but still plant them; they're good for us in so many ways) and concentrate on shellfish.

\section{CARBON SEQUESTRATION POTENTIAL OF SHELLFISH}

About half the mass of shellfish is shell, and shellfish-shell is solidified $\mathrm{CO}_{2}$. The difference is, it's permanently solidified (mineralised) $\mathrm{CO}_{2}$. Molluscan shell is a typical biomineral composed of $\mathrm{CaCO}_{3}$ with a small amount of matrix proteins included that direct the species-specific crystal growth; arthropod (crab, shrimp, lobster) exoskeletons are composed largely of chitin hardened with calciummagnesium carbonate nanocrystals (Boßelmann et al., 2007). 
$\mathrm{Ca}^{2+}$ is absorbed through specific transporters in the tissues of the animals and is reacted with $\mathrm{HCO}_{3}{ }^{2-}$, which is synthesized from $\mathrm{CO}_{2} . \mathrm{HCO}_{3}{ }^{2-}$ is partly absorbed directly from the surrounding water (or gaseous atmosphere for terrestrial species). The rest derives from $\mathrm{CO}_{2}$ generated by the animal's food through the TCA cycle. The fractions derived from these two sources differ widely (McConnaughey \& Gillikin, 2008; Filgueira et al., 2019). Knowing when calcification draws mainly on $\mathrm{CO}_{2}$ from food or depends on inorganic carbon from ambient air or water is a crucial consideration for studies of nutrition, ecology, conservation and cultivation but it is not relevant to this discussion. My only interest is mineralization of atmospheric $\mathrm{CO}_{2}$ in the shell. For animals which are filter feeders; the $\mathrm{CO}_{2}$ generated by their TCA cycles comes from digestion of plankton and is derived from planktonic photosynthesis (Tassanakajon et al., 2008). For terrestrial species the source is the photosynthesis of terrestrial plants. This is true even for predators, scavengers and detritus feeders, aquatic and terrestrial; all depend on fixation of photosynthetic carbon from the atmosphere at the root of the food chain. There is no other source of metabolic carbon.

Ultimately, then, the $\mathrm{CO}_{2}$ for the shell comes from the atmosphere and stays out of the atmosphere. Intact shellfish shells are excavated regularly from the middens associated with coastal Palaeolithic human communities (old Stone Age; from around 12,000 years ago). Intact shellfish shells abound in deep-water cores of ancient coastal sediments of hundreds of thousands of years ago. And remember the fossils from deep time: brachiopods (550 million years ago), trilobites (520 million years ago) and ammonites (240 - 65 million years ago). Certainly, these fossil shells are changed considerably in chemistry by now, but the shells survive over geological time in order to be fossilised; and in vast numbers. How much more permanent, do we need permanent to be?

The Food and Agriculture Organization of the United Nations Fisheries \& Aquaculture Department maintains a database of Global Aquaculture Production that contains statistics on production volume. In this respect 'Aquaculture' is understood to mean the farming of aquatic organisms including molluscs and crustaceans. Farming implies some form of intervention in the rearing process to enhance production, such as regular stocking, feeding, protection from predators, etc. Farming also implies individual or corporate ownership of the stock being cultivated. For statistical purposes aquatic organisms which are exploitable by the public as a common property resource, with or without appropriate licences, are the harvest of fisheries, not aquaculture.

\section{APPLICATIONS OF BIOTECHNOLOGY IN SHELLFISH CULTIVATION}

Data from FAO Fisheries and Aquaculture Information and Statistics Branch (as of 25 May 2019) show that over the years 2010 to 2017 aquaculture harvests across the globe totalled $53,512,850$ metric tonnes of crustaceans and 122,527,372 metric tonnes of molluscs (a combined total of 176,040,222 metric tonnes in 8 years). 
If we assume that the shell represents $50 \%$ of the animal's mass, then the total shellfish-shell produced was 88 million tonnes over 8 years; which is an average of 11 million tonnes of shell per year. Filgueira et al. (2019) arrive at a similar value for bivalve molluscs alone. I quote: "Taking into account the global annual production of cultured bivalves is $\approx 14 \times 10^{6}$ tons, including clams, cockles, oysters, mussels and scallops (www.fao.org reporting 2015 data) and assuming an average contribution of shell to total body weight of $50 \%$ (general ballpark figure given that this varies greatly between species), shell represents a residue (potential byproduct) of $\approx 7 \times 10^{6}$ tons, of which $95 \%$ is calcium carbonate."

Returning to my calculation, if we further assume that for both crustaceans and molluscs the shell is made from $\mathrm{CaCO}_{3}$; on a molar mass basis, carbon represents $12 \%$ of the mass of calcium carbonate. So, 11 million tonnes of shell per year is equivalent to 1.32 million tonnes of carbon per year being captured from the atmosphere by current aquaculture activities.

Global carbon emissions from fossil fuel use were 9.795 billion tonnes in 2014 (or 35.9 billion tonnes of carbon dioxide) [https://www.co2.earth/global-co2-emissions]. So, a thousand-fold increase in aquaculture would permanently remove about $14 \%$ of the global carbon emissions in each year.

Could that be done? Possibly. If we doubled aquaculture production of crustaceans and molluscs each year then from the 14th year we could be removing 10.7 billion tonnes of carbon from the atmosphere each year.

Sustained annual doubling may not be realistic; but this simple calculation indicates that with determined effort (and adequate finance) to vastly increase aquaculture production we could be permanently extracting significant amounts of carbon annually from the atmosphere within the timescale that is currently envisaged for carbon capture by vastly increased afforestation.

The carbon balance of the growth phase of the animals is not important. Nor is harvesting, though the animals within the shells could be a valuable source of animal protein (with the profits contributing to finance for further expansion in cultivation). However, because our emphasis is focused on the animal as shell, rather than the animal as food, our unharvested shellfish farms could be placed in waters polluted with toxic wastes or toxic microbes. The most relevant fact being that when the animal dies (either in the aquaculture farm or in your kitchen) it leaves behind a shell made of insoluble carbonates constructed using $\mathrm{CO}_{2}$ which is now permanently removed from the atmosphere. The same considerations apply to crustacea, freshwater shellfish, and land snails.

\section{MISSED OPPORTUNITIES}

Unlike the forestry industry and its trees, the shellfish industry does not seem to appreciate the atmosphere-positive aspects of its animals. Just a few examples will suffice to illustrate this. 
- The Shellfish Growers Climate Coalition website stresses the adverse effects on production due to ocean acidification, increasing seawater temperature and disruption caused by superstorms (Global Aquaculture Alliance website). Although, of course, if enhanced shellfish cultivation permanently sequestered a significant amount of atmospheric $\mathrm{CO}_{2}$, acidification would also reduce.

- Reduced calcification by marine algae due to ocean acidification in response to rising atmospheric $\mathrm{CO}_{2}$ is also a concern in research on coccolithophores (Iglesias-Rodriguez et al. 2008). The relevance of this is that from the mid-Mesozoic Era in our geological history, coccolithophores have been major calcium carbonate producers in the world's oceans, today accounting for about a third of the total marine $\mathrm{CaCO}_{3}$ production. Although both calcification and net primary production in these species are significantly increased by high $\mathrm{CO}_{2}$ partial pressures, the possibility that the algae could be used to trap atmospheric $\mathrm{CO}_{2}$ does not seem to have been recognised.

- It has been suggested that seaweed aquaculture to upscale offshore kelp forests could provide sufficient $\mathrm{CO}_{2}$ sequestration to mitigate climate change (Froehlich et al., 2019). This could certainly provide temporary carbon capture in the short term that would be a useful contribution, but while kelp forests solve the 'land-usage' issue, they still suffer from the same limitations as terrestrial forests. Specifically: when the plant material dies it is digested and the $\mathrm{CO}_{2}$ it has sequestered is returned to the atmosphere. The only permanently removed carbon would be in the crustaceans and molluscs that would undoubtedly flourish in the seaweed forest.

- The book Goods and Services of Marine Bivalves (Smaal et al., 2019) deals with a wide range of aquaculture topics including genomics-driven biotechnological innovations like new pharmaceuticals from molluscs, habitat and ecosystem-engineering modification in coastal protection by reef-building bivalves, water clarification services provided by their filter feeding and even shells as collector's items, but does not include a chapter dealing specifically with the potential service of extracting carbon from the atmosphere.

- Filgueira et al. (2019) make the closest approach but they conclude that the " $0.45 \mathrm{~g} \mathrm{CO}_{2}$ sequestered by the shell of each cultured mussel in Norway is hardly significant taking into account that a regular car produces more than $100 \mathrm{~g} \mathrm{CO}_{2}$ per km". Personally, I would expect more than one mussel in a serving; say, at least 20 . So, moules marinière for two persons would sequester about $20 \mathrm{~g} \mathrm{CO}_{2}$; in just one meal. Feeding the rest of the family and a few friends the same way could easily sequester that $100 \mathrm{~g} \mathrm{CO}_{2}$ and be much more beneficial for the atmosphere than ten meals of prime beef. Remember, the $\mathrm{CO}_{2}$ is permanently sequestered, but you'll be hungry again the next day; and, presumably, so will your neighbours. Filgueira et al. (2019) conclude "although this is far from solving a global problem, 
everything counts. In addition, it is important to re-emphasize that this comes at no cost or effort given that bivalves are cultured to produce food." I am suggesting a change of focus: culture the bivalves, and those other shellfish, to sequester permanently $\mathrm{CO}_{2}$ from the atmosphere and accept the food as the by-product.

\section{CONCLUSIONS}

My suggestion would be that a realistic plan might feature three prime targets:

A. Fund a development foundation that will invest cash immediately in every existing aquaculture enterprise with the aim of doubling their production each season for the next three to five seasons. This is unlikely to be easy because of perception that expansion of the shellfish industry could have negative environmental effects on coastal waters by exceeding the population size the environment can sustain (carrying capacity). There are also concerns about social issues (aesthetic loss) and a supposed "loss of nature" (Newell, 2007; Newell et al., 2019; Smaal \& van Duren, 2019). Such perceived negative environmental effects are not unique to shellfish cultivation and certainly have their parallels in large-scale tree planting (use of scarce agricultural land, loss of biodiversity in monocultures, as noted above).

B. Fund research programmes to study:

- existing aquaculture farming methods to adapt them to wider ranges of sites and locations (Newell et al., 2019) [imagine a mussel farm on every offshore wind turbine, every oil and gas rig, every pier, wharf and jetty, every breakwater or harbour wall]. Again, not easy: other people have rights, privileges, ownerships and fears and prejudices. But then, try suggesting it would be a good idea to plant a forest of oak trees in Trafalgar Square, the Avenue des Champs-Élysées, or National Mall and Memorial Parks in Washington, D.C.

- New aquaculture farming methods to establish new organisms and new methods to enhance incorporation of atmospheric carbon into shells.

C. Fund developmental research into high-technology programmes. Biotechnological research on aquaculture is well established (e.g. Rasmussen \& Morrissey, 2007; Xiang, 2015). A more unusual suggestion would be to determine whether we could grow coccolithophore algae in giant illuminated fermenters (maybe using the Quorn ${ }^{\mathrm{TM}}$ fermenters as a model; see Moore et al., 2020)? Perhaps we could harvest a sludge of insoluble plates of calcium carbonate from which we could build our own 'white cliffs of Dover', because using this calcium carbonate as a feedstock for cement production could replace the fossil limestone that is currently used to make quicklime (in 2014, cement production accounted for $6 \%$ of the fossil $\mathrm{CO}_{2}$ emissions from industrial sources). Our way of life uses a lot of cement. 
We need plenty of funding and the determination to do it. So, if there's anyone out there with the odd billion dollars to spare just let me know and l'll get the programme rolling ... but, for the moment, would anyone like another bowl of moules marinière; or maybe a crab salad?

\section{CONFLICT OF INTEREST}

The author has no conflicts of interest to declare.

\section{REFERENCES}

Bastin J.-F., Finegold Y., Garcia C., Mollicone D., Rezende M., Routh D., Zohner C.M. \& Crowthe, T.W. 2019. The global tree restoration potential. Science. 365: 76-79.

Boßelmann F., Romano P., Fabritius H., Raabe D. \& Epple, M. 2007. The composition of the exoskeleton of two crustacea: The American lobster Homarus americanus and the edible crab Cancer pagurus. Thermochimica Acta. 463, 1-2: 65-68.

Boysen L.R., Lucht W., Gerten D., Heck V., Lenton T.M. \& Schellnhuber H.J. 2017. The limits to global-warming mitigation by terrestrial carbon removal. Earth's Future. 5: 463-474.

Filgueira R., Strohmeier T. \& Strand, Ø. 2019. Regulating services of bivalve molluscs in the context of the carbon cycle and implications for ecosystem valuation. In: Goods and Services of Marine Bivalves (ed Smaal A., Ferreira J., Grant J., Petersen J. \& Strand Ø.), pp. 231-251. Springer Nature. Cham, Switzerland. Open access download: https://link.springer.com/content/pdf/10.1007\%2F978-3-319-96776-9_12.pdf.

Froehlich H.E., Afflerbach J.C., Frazier M. \& Halpern B.S. 2019. Blue growth potential to mitigate climate change through seaweed offsetting. Current Biology. 29 (18): 3087-3093.e3.

Global Aquaculture Alliance. https://www.aquaculturealliance.org/advocate/climatechange-impacts-unite-u-s-shellfish-farmers/

Iglesias-Rodriguez M.D., Halloran P.R., Rickaby R.E.M., Hall I.R. and 9 others (2008). Phytoplankton calcification in a high- $\mathrm{CO}_{2}$ world. Science. 320: 336-340.

IPCC. 2018. Special Report on the Impacts of Global Warming of $1.5{ }^{\circ} \mathrm{C}$ above Pre-Industrial Levels and Related Global Greenhouse Gas Emission Pathways. View this URL: https://www.ipcc.ch/sr15/.

Li A., Wang J. \& Bao B. 2019. High-efficiency $\mathrm{CO}_{2}$ capture and separation based on hydrate technology: A review. Greenhouse Gases: Science and Technology. 9 (2): 175-193. 
McConnaughey T.A. \& Gillikin D.P. 2008. Carbon isotopes in mollusk shell carbonates. Geo-Marine Letters. 28 (5-6): 287-299. DOI: https://doi.org/10.1007/s00367-008-0116-4.

Moore D., Robson G.D. \& Trinci A.P.J. 2020. 21st Century Guidebook to Fungi, second edition. Cambridge University Press. London, UK. pp 600. ISBN: 9781108745680; www.cambridge.org/9781108745680.

Newell C.R., Brady D. \& Richardson J. 2019. Farm-scale production models. In: Goods and Services of Marine Bivalves (ed Smaal A., Ferreira J., Grant J., Petersen J. \& Strand Ø.), pp. 485-506. Springer Nature. Cham, Switzerland. Open access download: https://link.springer.com/content/pdf/10.1007\%2F978-3-31996776-9_24.pdf.

Newell R.I.E. 2007. A framework for developing "ecological carrying capacity" mathematical models for bivalve mollusc aquaculture. Bulletin of the Fisheries Research Agency (Japan), 19: 41-51.

Rasmussen R.S. \& Morrissey M.T. 2007. Biotechnology in aquaculture: transgenics and polyploidy. Comprehensive Food Science and Food Safety. 6(1): 2-16.

Rinne-Garmston (Rinne), K.T., Peltoniemi K., Chen J., Peltoniemi M., Fritze H., Peltoniemi M. \& Mäkipää R. 2019. Carbon flux from decomposing wood and its dependency on temperature, wood $\mathrm{N}_{2}$ fixation rate, moisture and fungal composition in a Norway spruce forest. Global Change Biology. 25: 1852-1867.

Romano M.C., Anantharaman R., Arasto A., Ozcan D.C., Ahn H., Dijkstra J.W., Carbo M. \& Boavida D. 2013. Application of advanced technologies for $\mathrm{CO}_{2}$ capture from industrial sources. Energy Procedia. 37: 7176-7185.

Smaal A., Ferreira J., Grant J., Petersen J. \& Strand Ø. (eds). 2019. Goods and Services of Marine Bivalves. Springer Nature. Cham, Switzerland. 591 pp. Open access download: https://link.springer.com/content/pdf/10.1007\%2F978-3-31996776-9.pdf.

Smaal A.C. \& van Duren L.A. 2019. Bivalve aquaculture carrying capacity: concepts and assessment tools. In: Goods and Services of Marine Bivalves (ed Smaal A., Ferreira J., Grant J., Petersen J. \& Strand Ø.), pp. 451-483. Springer Nature. Cham, Switzerland. Open access download: https://link.springer.com/content/pdf/10.1007\%2F978-3-319-96776-9_23.pdf.

Tassanakajon A., Vatanavicharn T., Supungul P., Tang S., Amparyup P., Somboonwiwat K., Tharntada S., Takahashi J. \& Toyohara H. 2008. Biotechnology of marine invertebrates - advances in shrimp and shellfish. In: Fisheries for Global Welfare and Environment, 5th World Fisheries Congress 2008 (ed Tsukamoto K., Kawamura T., Takeuchi T., Beard T.D. Jr. \& Kaiser M.J.), pp. 221-239. 
TERRAPUB. Tokyo, Japan. http://www.terrapub.co.jp/ onlineproceedings/fs/wfc2008/index.html.

Watling R. \& Harper D.B. 1998. Chloromethane production by wood-rotting fungi and an estimate of the global flux to the atmosphere. Mycological Research. 102: 769-787.

Xiang J. 2015. Recent major advances of biotechnology and sustainable aquaculture in China. Current Biotechnology. 4: 296-310. 